\title{
The Importance of Trees and Nature in Community: A Review of the Relative Literature
}

\author{
William Elmendorf
}

\begin{abstract}
A growing body of literature and experience revolves around the beneficial and connected relationships among nature, social settings, and social processes like interaction. This literature argues that the natural environment is a critical component of personal and community pride and well-being and a stimulus for collaborative action. Furthermore, it argues that empowering people to become involved in the process of landscape and park creation and maintenance increases social interaction, builds community capacity, and supports both development of community and community. Tree plantings and other civic environmental projects can be used to promote both healthy environments and healthy social structure even in the most deteriorated neighborhoods. As such, participatory environmental projects are strong tools of community development, and the work of arborists and urban foresters can play an important part in the process of community.

Key Words. Civic environmentalism; community; community capacity; community development; empowerment; interaction; shared and structured symbols; tree planting.
\end{abstract}

Arborists and urban foresters often become involved in tree plantings, Arbor Day celebrations, and other civic environmental projects. They know that these projects are important, fun, and rewarding, but the deeper impacts that this type of work has on community is often overlooked or simply not known. From a personal and professional standpoint, it is important that arborists and urban foresters understand the concepts of community capacity, development of community, and community and the positive impact that their work with trees and people can have on these processes.

This article concentrates on the social benefits of trees and nature. It discusses the concept of community and the idea of using tree planting and other civic environmental projects to build and maintain community.

\section{A BRIEF REVIEW OF COMMUNITY}

Community is a favorite word of politicians and bureaucrats and the notion of community is a fundamental idea to most people. There are many definitions surrounding this concept of a fabric of local life. Family, supporting institutions (school, church, health care, local government, financial institutions), shared territory, social interaction, a common life, collective action, and a healthy environment are elements found in the definitions of community (Hillery 1955; Wilkinson 1991). Community has been conceptualized as having coincidence of service area, psychological identification with locality, supporting organizations, local autonomy in decision-making, and strength in the interaction among residents and between residents and institutions (Warren 1972). Wilkinson (1991) described three essential properties of community: 1) as a local ecology or an organization of social life that meets daily needs and allows for adaptation to change; 2) as a comprehensive interactional structure, or social whole, that expresses a full round of human interests and needs; and 3) as a bond of local solidarity represented in people acting together to solve common problems. Nisbet (1953) illuminated the definition of community in these words:
Community is founded on people conceived in their whole rather than in one or another role, taken separately, that they may hold in the social order. It draws its psychological strength from levels of motivation deeper than those of mere volition of interest. Community is a fusion of feeling and thought, of tradition and commitment, of membership and volition. Its archetype, both historically and symbolically, is the family, and in almost every type of genuine community the nomenclature of family is prominent (p. 77).

The foundation of community is social interaction; individuals and groups working together and pursuing commonly held goals (Luloff and Swanson 1995). From an interactionist's perspective, social interaction is what creates the fabric of community; it encourages and allows the emergence and development of community (Hillery 1955). Community has been defined as an aggregate of people sharing a common interest in a particular locality, and Bender (1978) described community as having an interactional quality that allowed it to be defined as experience reinforced by space. Thus, community is just not a place; it is a place-oriented process. In this process, the physical characteristics and qualities of place, or environment, are recognized as playing important roles in the health, interaction, and capacity of community.

\section{A BRIEF REVIEW OF COMMUNITY DEVELOPMENT}

In community development, the quality of social interaction, or the comprehensive network of collaboration and actions among people, institutions, and the physical and natural environments, is important. Those interested in the development of community are interested in the quality of relationships among residents, institutions, and environments of a locality. Development of community requires attention to cohesive and integrated economic, social, and environmental structures (Kaufman 1959; Wilkinson 1991). Modern theories of sustainable community 
development, or smart growth (Hall and Porterfield 2001), are related to both older theories of neighborhood design (Perry 1939) and development of community (Wilkinson 1991) and explicitly recognize the interdependence of economic, social, and environmental factors (Ahern and Fabel 1988).

In progressive theory, development of community is more than enterprise development. Although economic goals are an overriding objective in many community development projects, economic gain without development of community can be divisive, exploitative, and unsustainable. Community development must include the experiences provided by attempts and successes of residents to strengthen themselves and their community. This work is facilitated by an interactional perspective of local society where channels of cooperation and communication are empowered and maintained, where human relationships are supported and strengthened, and where a shared concept of improvement is mutually developed. A developed community is both improved and its people empowered through skills and experiences, and a healthy physical and natural environment supports this type of progressive work (Kaufman and Wilkinson 1967; Wilkinson 1991). Community development focuses on places, economics, people, programs, and environments together. It is all of these and a well-woven, integrated social fabric resulting from adequate planning and integration of activities that meet peoples' day-to-day needs (Kaufman and Wilkinson 1967).

\section{TREES AND NATURE AS SOCIAL ELEMENTS}

In addition to environmental (Dwyer et al. 2000), human health (Ulrich 1983; Kuo and Sullivan 2001), economic (Irwin 2002; Lutzenhiser and Nolusil 2002), educational (Nowak et al. 2001), youth (Taylor et al. 1998; Kuo 2003), and safety and civility (Kuo 2003) values, the natural environment plays a significant role in the healthy and successful social lives of people by providing shared and structured symbols. These symbols (e.g., historical buildings and landscapes, monuments, trees, hills) help ground people in their everyday lives, and as change occurs, they provide residents with a consistent sense of place and comfort (Appleyard 1979; Hester 1990). Trees and landscapes can be shared and structured symbols, caring and supportive symbols that become part of the identity and features of a place that invoke pride, attract outside attention, and stimulate economic activity (U.S. Environmental Protection Agency 2002). Alexander et al. (1977) pointed out:

Trees have a very deep and crucial meaning to human beings. The significance of old trees is archetypical; in our dreams they often stand for the wholeness of personality. The trees people love create special places; places to be in and places to pass through. Trees have the potential to create various kinds of social places (p. 798).

Trees, parks, and other components of the natural environment become powerful social symbols when they are perceived as being part and representative of a social group (such as a neighborhood), especially when nature plays an influential role in relationship to social functions such as family, home, play, love, health, and equality (Appleyard 1979). Nature again proves important because the sense of self in place is more important than simply a sense of place, and people's relationship with their natural environment can help build a stronger connection to their place (Hester 1990). As such, the significance of nature's social role in reinforcing a sense of locality or place plays an influential role in community development. Trees and other natural features help to create and maintain a sense of place; that is a feeling of identification and belonging that is important to people's enjoyment and well-being and to the process of community.

Very strong emotional ties can exist between people and elements of natural settings such as trees (Dwyer et al. 1991, 1992). Greider and Garkovich (1994) argued that landscapes can be "the symbolic representation of a collective local history and the essence of a collective self-definition." Social meaning and intention can heighten in cases of environmental conflict or opportunity, and inversely, environmental conflict and opportunity occurs in cases in which social meaning is especially critical (Appleyard 1979). Greider and Garkovich (1994) discussed the social connection between people and their natural environment:

.. That what is important in any consideration of environmental change is the meaning of the change for those cultural groups that have incorporated that aspect of the physical environment into their definition of themselves (p. 21).

Taken together, these values of trees and nature support the capacity of community to develop and the process of community. They illustrate the important connections between people and nature even in highly urbanized places and their value in community development strategies.

\section{A DEEPER LOOK AT NATURE AND COMMUNITY DEVELOPMENT}

Many early social ecologists viewed the natural environment as a featureless surface on which social patterns and relationships distributed themselves (Firey 1947). Today there are much different ideas about the relationship of nature to social settings and processes (Wilkinson 1979, 1991; Nowak et al. 2001). Many authors suggest that ecological well-being is a critical component of both individual and community well-being. A sociologist named Wilkinson (1991) discussed this thought:

Social and individual well-being cannot be achieved except in ways that also promote ecological well being. Ecological well-being, which in a literal sense means the wellbeing of the house of civilization, refers explicitly to natural and other conditions that support and sustain human life. It is not accurate or appropriate to treat the environment as though it was somehow separate from the social life it supports. An active interdependency characterizes the relationship between social life and its surroundings. References to human and environment separation cannot be justified on any grounds today, if they might have been justified heuristically in the past (p. 75).

Wilkinson (1991) described the potential for increasing both human and community capacity as growing from an intimate relationship of trust of both self and society. Both the ability to establish trust and the potential for capacity is suppressed by deficits in meeting primary human needs and social and cultural patterns (housing, education, health care, safety, political representation, recreation) that discourage interaction and community work. These "patterns" also include environmental racism and 
unhealthy natural environments, or phrased differently, healthy natural environments that are not freely accessible to all people.

Social ecologists and other authors argue that healthy and accessible natural environments provide opportunities for people to interact and generalize across interest lines. These opportunities help develop community, places characterized by shared spatial experiences and concern (Wilkinson 1991). Promoting the development of technology and economy, the interaction of people, and healthy environmental surroundings are all crucial for community. An active interdependence characterizes the relationship between productive community life and healthy and accessible environmental surroundings (Ahern and Fabel 1988).

\section{USING TREES AND NATURE FOR COMMUNITY CAPACITY}

Community capacity is simply defined as the strengths and assets of community members both individually and collectively brought to a cause. It is related to the term organizational capacity, or the ability to do meaningful work. Frank and Smith (1999) described community capacity this way:

... It is the ways and means needed to do what has to be done. It is broader than simple skills, people, and plans. It includes commitment, resources, and all that is brought to bear on a process to make it successful (p. 26).

Building community capacity, or the ability of the people of a place to work together toward common goals, is one critical stepping stone in community.

As has been discussed, interaction and participation in are essential parts of positive community change. As people's public activity and experience increase, so do the levels of community capacity (Wilkinson 1979; Cottrell 1983; Ayers and Potter 1989). Whether they realize it or not, arborists and urban foresters find themselves involved in building community capacity, especially when they are working with participatory and educational programs and projects. The degree to which community members identify with and enjoy nature and interact in the planning, maintenance, and use of trees and public landscapes is one of the interrelated factors important in building community capacity. First, public landscapes and parks are more effective in meeting local people's needs if they are very involved in planning, decision-making, and building. Second, highly participatory environmental projects can promote social structure and organization even in the most deteriorated neighborhoods by building interaction and capacity through block clubs, neighborhood organizations, church groups, and public and private partnerships (McDonough et al. 1991). The degree to which people are educated and involved in docent programs, tree plantings, environmental restoration projects, and other environmental volunteer and educational work can increase positive identification with a locale; increases the quality of relationships among people and between organizations; increases public knowledge, networking, and experience; increases community capacity; and helps the development of community to occur (Rudel 1989; Lipkis and Lipkis 1990; Maslin et al. 1999).

Many case studies of inner-city projects in which arborists and urban foresters are closely involved support using the natural environment as a vehicle to build community capacity in the development of community (Shutkin 2000). These descriptions of practical endeavors agree that planning for, maintaining, and managing trees and public landscapes does build community capacity, which supports community development. In addition to supporting healthy neighborhoods and communities, tree planting and other environmental projects have been repeatedly used by organizations such as Philadelphia Green, TreesAtlanta, Friends of the San Francisco Urban Forest, Los Angeles TreePeople, and New York GreenGorillas to rebuild the sense and capacity of community and ameliorate the effects of drugs, crime, violence, apathy, and despair in often seemingly hopeless neighborhood settings:

Planting a tree enables a person to have an immediate, tangible, and positive effect on their environment. It fosters community pride and opens channels for individuals to meet their neighbors, tackle community problems, and build neighborhood associations (Kollin 1987, p. 96).

Tree planting fosters community spirit and pride, bringing people together for meaningful purpose that can build the bridges and promote the understandings that bring the neighborhood together. The initial efforts of the tree planters compound themselves as others find in the trees a deeper appreciation of the community as well as natural beauty. It is the beginning of the formation of new values that is the foundation for city-wide transformation. The newly organized group can further push for bike paths, improvements in public transportation, and changes to make the area less congested, less polluted, and more livable (Lipkis and Lipkis 1990, p. viii).

Planning and completing tree planting, urban gardening, and other types of green projects inspires neighborhood and community groups to change the environment of their streets (neighborhooding), giving a new understanding of and character to their neighborhood and to the city as a whole (Schrieber and Vallery 1987, p. 14).

The simple act of planting a tree, along with the more complicated projects of civic environmental restoration, has positive effects on the economic, social, and environmental elements of community. These types of actions are especially important in ignored and disenfranchised places where the battle cry of community capacity is "celebrate any success."

\section{CONCLUSION}

Environmental projects are increasingly being completed for social objectives and the language of empowerment is often used by practitioners to describe the benefits provided from them (Westphal 2003). Some authors believe that practitioners often overstate the social benefits provided from environmental projects. As a result, they have reviewed the indicators of empowered or empowering (increased skills, access to resources, networking) and their role in both projects and community. They have also divided the benefits of civic environmental projects into individual, organizational, and community-level, questioning whether benefits derived by individuals and organizations always provide the public good of community (Westphal 2003). Other authors argue that collective actions and experiences by groups of people working toward common goals fundamentally increase community capacity (Wilkinson 1979). The study of 
community development and community continues to be complicated and the human side of urban forestry provides excellent opportunities for inquiry.

There are concepts that should be considered to better integrate environmental projects into the process of community. For people who want to do something about community, Wilkinson (1998) has described a number of these ideas: 1) community development is about the development of a human relationship structure, it is not just about things; 2) community development must reflect and express the values and wishes of the local population; 3) community requires interaction and interaction requires trust, communications, and cooperation; 4) community development requires a commitment beyond selfish gain; and 5) community development requires that attention be given to all areas of local life. He also pointed out the necessity of a highquality and accessible natural environment for community. Interestingly, in many ways, these community development concepts can be supported by the involvement of arborists and urban foresters in tree plantings and other civic environmental projects.

The field of civic environmentalism has been described as a local reaction to topdown regulations and projects. It has been expressed in the context of civic renewal, community problemsolving, and participatory democracy. Additional ideas to help better tie environmental projects into community may be found in this emerging field and include (Sirianni and Friedland 2001): 1) working to increase knowledge and collaboration among local people and between people and organizations, including new skills and experiences, access to resources, and networking; and 2) developing public works projects that directly engage citizens in monitoring, improving, and restoring the places in which they live. A fundamental concept here is that environmental projects, landscapes, and policy imposed on people by outsiders can mean and do little for community. There must be collective participation by local people for increased community development. These participatory ideas should be supported by arborists and urban foresters in tree plantings and other participatory environmental projects.

From social, human health, and economic standpoints, tree planting, urban gardening, and other collaboratively planned and completed environmental projects are some of the simplest, most rewarding, and most celebrated actions that can be used to build and maintain community. This is especially true in deteriorating and disenfranchised neighborhoods. It is clear that accessible high-quality environments and place-oriented environmental projects help increase the overall quality of a place's interaction and capacity. In a 2003 study, Kuo notes:

\section{The link between trees and a healthy social system turns out to be surprisingly simple to explain. In residential areas, barren, treeless spaces become no man's land, which discourages residential interaction and invites crime. The presence of trees and maintained landscapes can transform these no man's lands into pleasant, wel- coming, well used spaces that serve to both strengthen ties among residents and deter crime (p. 154).}

How much do tree planting and other civic environmental projects do for community development? The long-term answer is whether a critical mass of required community development activities can be completed to move a place forward. This said, by their ability to provide for both healthier environments and community capacity, tree plantings and other environmental projects can be powerful community development tools. However, it should be understood that their use alone will not overcome the immense problems when considering those places faced with drugs, anger, violence, disinvestment, and poverty.

\section{LITERATURE CITED}

Ahern, J., and J. Fabel. 1988. Linking the global with the local: Landscape ecology, carrying capacity, and the sustainable development paradigm, pp. 1-7. In Proceedings of the Landscape/Land Use Planning Committee of the American Society of Landscape Architecture. American Society of Landscape Architecture, Washington, DC.

Alexander, C., S. Ishikawa, and M. Silverstein. 1977. A Pattern Language: Towns, Buildings, Construction. Oxford University Press, New York.

Appleyard, D. 1979. The environment as a social symbol within a theory of environmental action and perception. American Planning Association Journal. April:143-153.

Ayers, F., and H. Potter. 1989. Attitudes toward community change: A comparison between rural leaders and residents. Journal of the Community Development Society 20:1-18.

Bender, T. 1978. Community and Social Change in the United States. Rutgers University Press, New Brunswick, NJ.

Cottrell, L. 1983. The competent community, pp. 402-412. In Warren, R., and L. Lyon (Eds.). New Perspectives on the American Community. Dorsey Press, Homewood, IL.

Dwyer, J., H. Schroeder, and P. Gobster. 1991. The significance of urban forests: Towards a deeper understanding of values. Journal of Arboriculture 17:276-284.

Dwyer, J., E. McPherson, H. Schroder, and R. Rountree. 1992. Assessing the benefits and costs of the urban forest. Journal of Arboriculture 18:227-234.

Dwyer, J., D. Nowak, M. Noble, and S. Sisinni. 2000. Connecting People With Ecosystems in the 21st Century: An Assessment of our Nation's Urban Forests. USDA Forest Service, Washington, DC.

Firey, W. 1947. Land Use in Central Boston. Harvard University Press, Cambridge, MA.

Frank, F., and A. Smith. 1999. The Community Development Handbook: A Tool to Guide Community Capacity. Human Resources Development Canada, Quebec, Canada.

Greider, T., and L. Garkovich. 1994. Landscapes: The social construction of nature and the environment. Rural Sociology 59:1-14.

Hall, K., and G. Porterfield. 2001. Community by Deign: New Urbanism for Suburbs and Small Communities. McGraw Hill, New York.

Hester, R. 1990. The Sacred Structure in Small Towns: A Return to Manteo, North Carolina. Small Town (January-February):26-32.

Hillery, G. 1955. Definitions of community: Areas of agreement. Rural Sociology 20:111-125.

Irwin, E. 2002. The effects of open space on residential property values. Land Economics 38:468-480.

Kaufman, H. 1959. Toward an interactional conception of community. Social Forces 38:8-17.

Kaufman, H., and K. Wilkinson. 1967. Community Structure and Leadership: An Interactional Perspective in the Study of Community. Research Bulletin 13, Mississippi State University Social Science, Starkville.

Kollin, C. 1987. Citizen action and the greening of San Francisco, pp. 96-99. In Phillips, A., and D. Gangloff (Eds.). Proceedings of the Third National Urban Forestry Conference. American Forestry Association, Washington, DC.

Kuo, F. 2003. The role of arboriculture in a healthy social ecology. Journal of Arboriculture 29:148-155.

Kuo, F., and W. Sullivan. 2001. Aggression and violence in the inner city: Effects of environment via mental fatigue. Environment and Behavior 33:775-795. 
Lipkis, A., and K. Lipkis. 1990. The Simple Act of Planting a Tree. Jeremy Tarcher, Los Angeles.

Luloff, A., and K. Swanson. 1995. Community agency and disaffection: Lessons for enhancing collective resources, pp. 351-372. In Beaulieu, L., and D. Mulkey (Eds.). Investing in People: The Human Capital Needs of Rural America. Westview Press, Boulder, CO.

Lutzenhiser, M., and N. Nolusil. 2001. The effect of open space on a home's sale price. Contemporary Economic Policy 19:291-298.

Maslin, M., P. Vu, and C. Kidd. 1999. Philadelphia Green Presents the Tree Tenders Handbook. The Pennsylvania Horticulture Society, Philadelphia, PA.

McDonough, M., W. Burch, and M. Grove. 1991. The urban resource initiative, pp. 75-76. In Rodbell, P (Ed.). Proceedings of the Fifth National Urban Forest Conference. American Forestry Association, Washington, DC.

Nisbet, R. 1953. The Quest for Community: A Study in the Ethics of Order and Freedom. Oxford Press, New York.

Nowak, D., M. Noble, S. Sisinni, and J. Dwyer. 2001. People and trees: Assessing the United States' urban forest resource. Journal of Forestry 99:37-42.

Perry, C. 1939. Housing for the Mechanical Age. Russell Sage Foundation, New York.

Rudel, T. 1989. Situations and Strategies in Land Use Planning. Cambridge University Press, New York.

Schrieber, P., and A. Vallery. 1987. Philadelphia green: An outreach program. In Phillips, A., and D. Gangloff (Eds.). Proceedings of the Third National Urban Forestry Conference. American Forestry Association, Washington, DC. $106 \mathrm{pp}$

Shutkin, W. 2000. The Land That Could Be: Environmentalism and Democracy in the Twenty-First Century. The MIT Press, Cambridge, MA.

Sirianni, C., and L. Friedland. 2001. Civic Innovation in America: Community Empowerment, Public Policy, and the Movement for Civic Renewal. University of California Press, Berkeley, CA.

Taylor, A., A. Wiley, F. Kuo, and W. Sullivan. 1998. Growing up in the inner city: Green spaces as places to grow. Environment and Behavior 30:3-27.

Ulrich, R. 1984. View through a window may influence recovery after surgery. Science 224:420-421.

U.S. Environmental Protection Agency. 2002. Community, Culture, and the Environment: A Guide to Understand Sense of Place. EPA 842B-01-03. U.S. EPA, Washington, DC.

Warren, R. 1972. The Community in America. Rand McNally, Chicago.

Westphal, L. 2003. Urban greening and social benefits: A study of empowerment outcomes. Arboriculture and Urban Forestry 29: 137-147.

Wilkinson, K. 1979. Social well-being and community. Journal of the Community Development Society 10:5-16.

. 1991. The Community in Rural America. Greenwood Press, New York.

1998. The community: Its structure and process, pp. 86-90. In Zuber, E., S. Nelsen, and A.E. Luloff (Eds.). Community: A Biography in Honor of the Life and Work of Ken Wilkinson. The Northeast Regional Center for Rural Development, University Park, PA.
William Elmendorf

Assistant Professor of Community Forestry

334 Forest Resources Building

University Park, PA 16802, U.S.

Wfel@psu.edu

Résumé. Une masse croissante de littérature et d'expériences tourne autour des bénéfices et des relations inter reliées entre la nature, les groupes sociaux et les processus sociaux interactifs. Cet article traite de l'environnement naturel en tant que composante critique du bien-être et de fierté personnelle et communautaire ainsi qu'en tant que stimuli de l'action collective. Il traite même du fait que cela permet d'accroître le désir de la population à s'impliquer dans le processus de création et d'entretien des aménagements et des parcs, ce qui augmente l'interaction sociale, construit des capacités pour la communautés et supporte à la fois le développement de la communauté et la communauté elle-même. Les plantations d'arbres et autres projets civiques environnementaux peuvent être utilisés pour promouvoir à la fois des environnements et une structure sociale saines, et ce même dans les quartiers les plus défavorisés. De ce fait, la participation à des projets environnementaux constitue un outil de développement communautaire et le travail des arboriculteurs ainsi que des forestiers urbains peut jouer un rôle important dans le développement de la communauté

Zusammenfassung. Es gibt ein Wachstum in Literatur und Erfahrung um die Vorteile und verbundenen Beziehungen zwischen Natur, sozialen Gegebenheiten und sozialen Prozessen, wie Interaktionen. Die Literatur argumentiert, dass die natürliche Umgebung eine entscheidende Komponente des persönlichen und kommunalen Wohlergehens und damit ein Stimulus für kollektives Handeln ist. Darüber hinaus sagt sie aus, dass die Einbeziehung von Menschen in den Prozess von Landschaftsgestaltung und Pflege das soziale Miteinander und den Gemeinschaftssinn fördert und die Entwicklung von Gemeinschaft unterstützt. Baumpflanzungen und andere Umweltprojekte können dazu beitragen, sowohl eine gesunde Sozialstruktur als auch eine gesunde Umwelt, sogar in wirklich heruntergekommenen Umgebungen zu fördern. Folglich können gemeinschaftliche Umweltprojekte einen großen Beitrag für kommunale Entwicklung leisten. Die Arbeit von Baumpflegern und Stadtforstwirten kann eine wichtige Rolle dabei spielen.

Resumen. Un creciente cuerpo de literatura y experiencia giran en torno a las relaciones entre la naturaleza, los escenarios sociales, y la interacción con los procesos sociales. Esta literatura argumenta que el ambiente natural es un componente crítico del bienestar y orgullo personal y comunitario y un estímulo para la acción colectiva. Es más, se arguye que la fuerza de la gente, al verse envuelta en el proceso de creación y mantenimiento de paisajes y parques, incrementa la interacción social, construye la capacidad comunitaria, y apoya el desarrollo de la comunidad. La plantación de árboles y otros proyectos cívicos ambientales pueden ser usados para promover ambientes saludables y fuertes estructuras sociales en la mayoría de vecindarios deteriorados. De esta manera, los proyectos ambientales participantes son fuertes herramientas en el trabajo de los Arboristas y Dasónomos Urbanos, que pueden jugar una parte importante en el desarrollo comunitario. 